\title{
DETERMINATION OF NORMALIZED DIFFERENCE VEGETATION INDEX USING REMOTE SENSING AND GIS (A Case Study of River Duruji Basin, Kvareli Municipality, Georgia)
}

\author{
Irma Inashvili, Dr., Professor, Georgian Technical University, Georgia \\ ORCID: https://orcid.org/0000-0002-6202-4580 \\ Konstantine Bziava, Dr., Associate Professor, Georgian Technical University, Georgia \\ ORCID: https://orcid.org/0000-0003-1237-5224 \\ Irina Denisova, Dr., Assistant Professor, Georgian Technical University, Georgia \\ ORCID: https://orcid.org/0000-0002-3807-0042 \\ Marina Shogiradze, PhD Student, Georgian Technical University, Georgia
}

\section{DOI: https://doi.org/10.31435/rsglobal_conf/30052021/7571}

\begin{abstract}
Soil erosion is a complex and multifaceted process. Both natural and anthropogenic factors determine its origin and development. The object of the initial study of water erosion is erosion that develops on mountain slopes, which in a short period of time proceeds with a greater intensity than the erosion of lowland rivers and canals. It should be noted that the territory of Georgia is distinguished by a complex and fragmented relief, with a pronounced vertical zoning, therefore, within controlling the soil erosion on the slopes, special importance is attached to the green cover (vegetation).

Based on the above, the article examines the Normalized Difference Vegetation Index (NDVI) of the Duruji River Basin for 2013 and 2020, and also analyses the dynamics of changes in the vegetation cover. It was found that the annual increase in the Non-vegetation area is about 13.94 hectares, with sparse-vegetation - 63.10 hectares and with Moderate vegetation - 20.06 hectares, due to which the area with Dense-Vegetation decreased by 97.10 hectares. It has been substantiated that if this growth trend persists, by 2030 it is expected that about 100 hectares of vegetation cover will be lost.
\end{abstract}

Keywords: Erosion, relief, slope, vegetation cover, Normalized Difference Vegetation Index (NDVI).

Introduction. A characteristic feature of vegetation and its condition is spectral reflectivity, characterized by large differences in the reflection of radiation of different wavelengths. Knowledge of the relationship between the structure and state of vegetation and its reflectivity makes it possible to use satellite images to identify types of vegetation and their state.

Currently, there are about 160 variants of vegetation indices. They are selected experimentally (empirically) based on the known features of the curves of the spectral reflectance of vegetation and soils.

The most popular and frequently used vegetation index is NDVI (Normalized Difference Vegetation Index), which takes positive values for vegetation and the higher the value of green phytomass, the higher it is. The values of the index are also influenced by the species composition of vegetation, its closeness, condition, exposure and angle of inclination of the surface, and the colour of the soil under sparse vegetation.

The main advantage of vegetation indices is the ease of obtaining them and a wide range of tasks solved with their help. Thus, the NDVI is often used as one of the tools for carrying out more complex types of analysis, the result of which can be maps of the productivity of forests and agricultural lands, maps of landscapes and natural zones, soil, arid, phytohydrological, phenological and other ecological and climatic maps.

The Normalized Difference Vegetation Index (NDVI) is a radiometric measurement of photosynthetically absorbed radiation above the earth's surface. It is used to analyse the difference between near-infrared light, which is strongly reflected by vegetation, and red light, which is absorbed by vegetation. The NDVI data provides accurate data on the presence of living green vegetation on the surveyed land plot and allows you to focus on problem areas that may require additional attention [1, 2, 3, 4, and 5].

Study area. Kvareli municipality is located in the north-eastern part of the Kakheti region of Georgia. The town of Kvareli is the administrative canter of the municipality. The area of the region is 
about $1000.8 \mathrm{~km}^{2}$. From the east, south and west it borders with the municipalities of Lagodekhi, Gurjaani and Telavi, from the north along the Great Caucasus Ridge runs the border with the Russian Federation.

In Kvareli municipality the altitude ranges from $240 \mathrm{~m}$ to $3100 \mathrm{~m}$, so the climatic conditions at different heights are various. In the southern part of the municipality, in the lowland (240-400 $\mathrm{m}$ above sea level), where the Alazani Valley is spread out, the climate is characterized by mild cold winter and warm summer. Here the annual average air temperature is about $8-9{ }^{\circ} \mathrm{C}$. To the north, the Alazani Valley passes into the foothills and then into the Kakheti highlands. Above $1800 \mathrm{~m}$, the average annual temperature drops to $3-4{ }^{\circ} \mathrm{C}[6,7]$. The main climatic data for Kvareli municipality are shown in Table 1 [8].

Table 1. Climate data for Kvareli municipality (Long-term average)

\begin{tabular}{|c|c|}
\hline \multicolumn{1}{|c|}{ Climate characteristics of region } & Data \\
\hline Temperature: & \\
\hline - Average annual & $9,4-10,4^{\circ} \mathrm{C}$ \\
\hline -In summer months & $18,5-19,1^{\circ} \mathrm{C}$ \\
\hline Total precipitation: & \\
\hline - Average annual & $817-968 \mathrm{~mm}$ \\
\hline -In summer months & $253-303 \mathrm{~mm}$ \\
\hline Average annual wind speed & $1-2 \mathrm{~m} / \mathrm{s}$ \\
\hline
\end{tabular}

The main economic sector of Kvareli municipality is agriculture. Agricultural land occupies about 35 thousand hectares, of which 13355 ha are arable land, 10290 ha - perennial plantations and 11439 ha pastures. Non-agricultural plots of land occupies 6055 ha, while forests and shrubs - 58941 ha [2].

The district is dominated by carbonate-clay loams, alluvial non-calcareous, skeletal, grey-brown forest and grey-brown meadow soils, which contribute to agricultural activities, in particular the cultivation of unique grape varieties. Most of the high-altitude area (600-3000 m ASL) is covered with forests, shrubs and grasslands, as well as fruit trees. Below (400-600 m ASL), the land is mostly occupied by perennial crops, mainly vineyards. There are also plantings of peaches, persimmons and nuts.

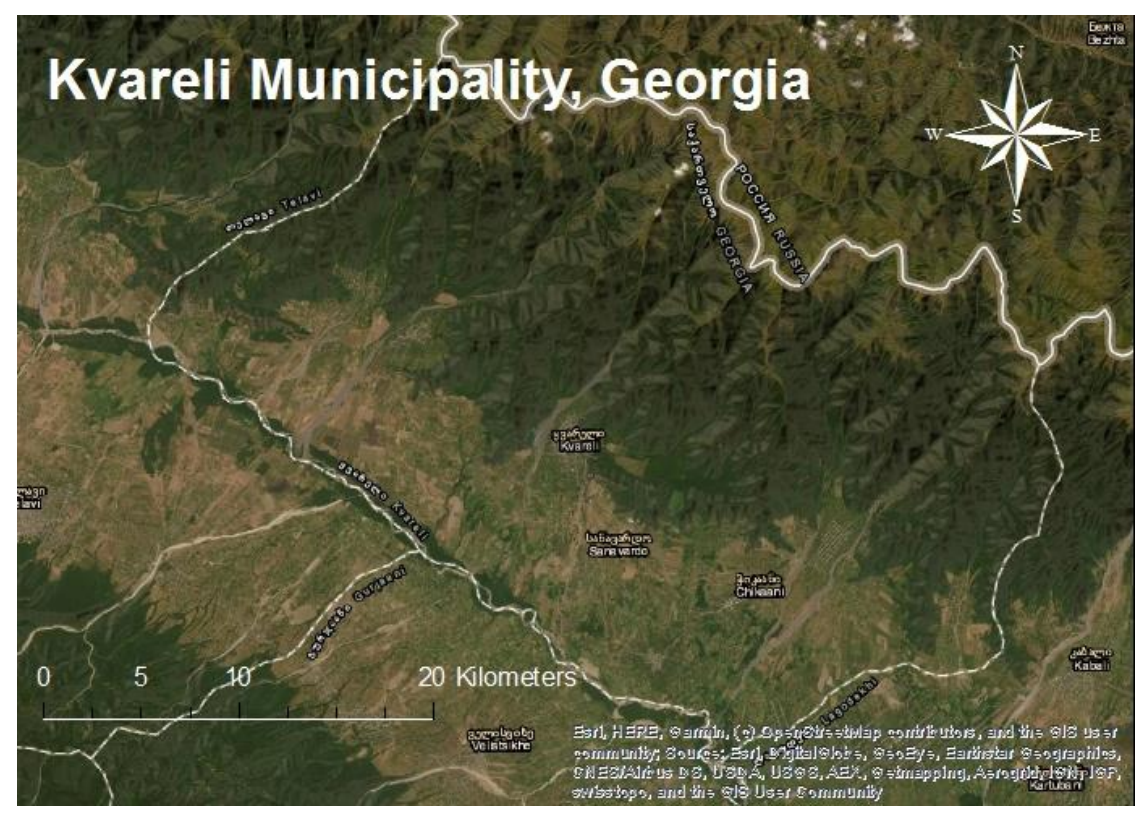

Fig. 1. Kvareli Municipality, Georgia

Methodology. Panchromatic band is used for increase the resolution of data. Landsat 7 data having total of 8 band while Landsat 8 data having 11 bands. Landsat 7 and Landsat 8 data's bands, wavelength and their resolution are provided below (see Table 2) [9]. 
Table 2. Landsat 8 Operational Land Image (OLI) and Thermal Infrared Sensor (TIRS)

\begin{tabular}{|c|c|c|c|c|c|c|c|}
\hline \multirow{2}{*}{ S.N. } & \multicolumn{3}{|c|}{$\begin{array}{c}\text { Landsat } 7 \text { Enhanced Thematic Mappers } \\
\text { Plus (ETM+) }\end{array}$} & \multirow{2}{*}{ Band } & \multicolumn{3}{|c|}{$\begin{array}{c}\text { Landsat } 8 \text { Operational Land Imagers } \\
\text { (OLI) \& Thermal Infrared Sensor (TIRS) }\end{array}$} \\
\hline & $\begin{array}{c}\text { Resolution } \\
\text { (meter) }\end{array}$ & $\begin{array}{l}\text { Wavelength } \\
\text { (micrometre) }\end{array}$ & Band Name & & Band Name & $\begin{array}{r}\text { Wavelength } \\
\text { (micrometre) }\end{array}$ & $\begin{array}{c}\text { Resolution } \\
\text { (meter) }\end{array}$ \\
\hline 1 & 30 & $0.45-0.52$ & Blue & Band 1 & Ultra-Blue & $0.435-0.451$ & 30 \\
\hline 2 & 30 & $0.52-0.60$ & Green & Band 2 & Blue & $0.452-0.512$ & 30 \\
\hline 3 & 30 & $0.63-0.69$ & Red & Band 3 & Green & $0.533-0.590$ & 30 \\
\hline 4 & 30 & $0.77-0.90$ & NIR & Band 4 & Red & \begin{tabular}{|l}
$0.636-0.673$ \\
\end{tabular} & 30 \\
\hline 5 & 30 & $1.55-1.75$ & SWIR11 & Band 5 & NIR & 0.851-0.879 & 30 \\
\hline 6 & $60 *(30)$ & $10.40-12.50$ & Thermal & Band 6 & SWIR 1 & 1.566-1.651 & 30 \\
\hline 7 & 30 & $2.09-2.35$ & SWIR 2 & Band 7 & SWIR 2 & $2.107-2.294$ & 30 \\
\hline 8 & 15 & $0.52-0.90$ & Panchromatic & Band 8 & Panchromatic & $0.503-0.676$ & 15 \\
\hline 9 & & & & Band 9 & Cirus & $1.363-1.384$ & 30 \\
\hline 10 & & & & Band 10 & TIRS 1 & \begin{tabular}{|l}
$10.60-11.19$ \\
\end{tabular} & $100 *(30)$ \\
\hline 11 & & & & Band 11 & TIRS 2 & $11.50-12.51$ & $100 *(30)$ \\
\hline
\end{tabular}

For analysis of Normal Difference Vegetation Index (NDVI), only 2 bands are used (Red \& NIR) from USGS, Landsat 8 (see Fig. 2 and Fig. 3):

1. Band 4 - red. Wavelength 0.64-0.67. This map is useful for mapping discriminates vegetation slopes;

2. Band 5 - near Infrared (NIR). Wavelength $0.85-0.88$. This map is useful for mapping emphasizes biomass content and shorelines;
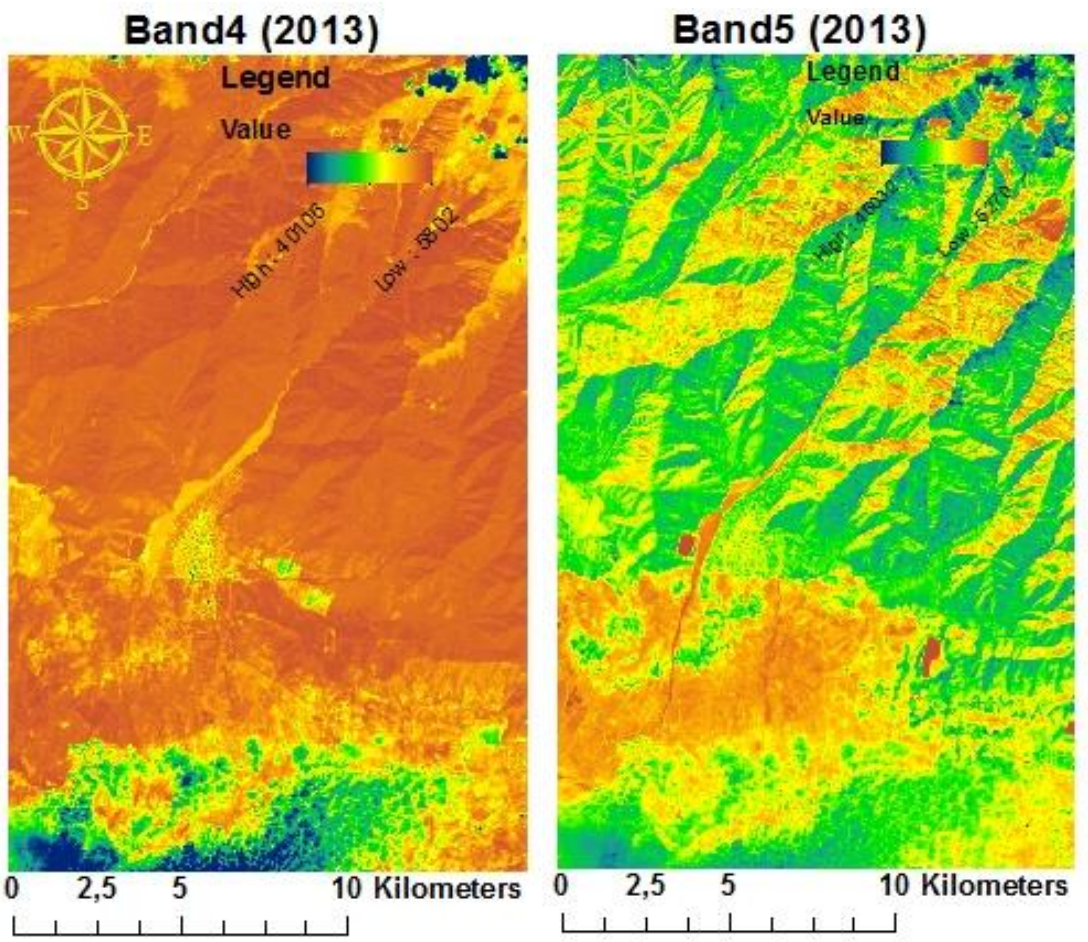

Fig. 2. Band 4 - Red Band and Band 5 - Near Infra-Red (NIR) from Landsat 8 (September, 2013, River Duruji Basin) 

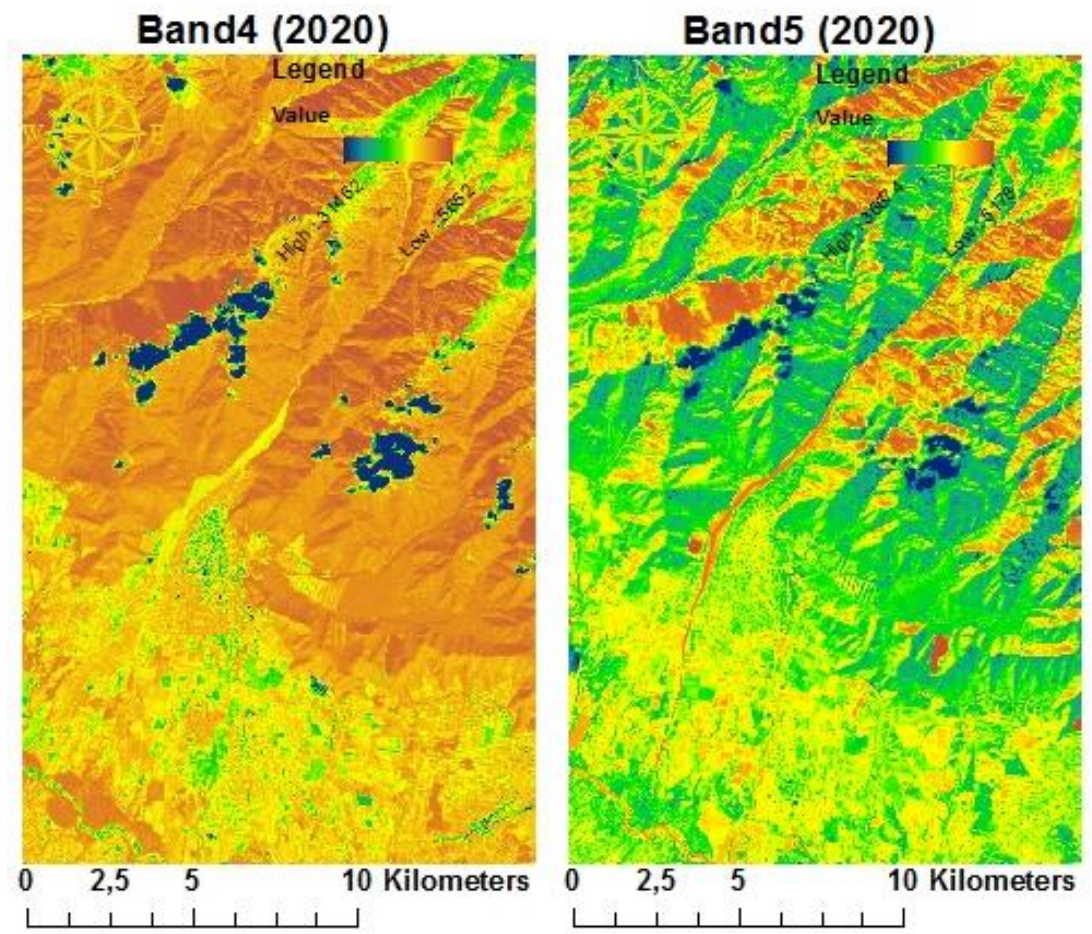

Fig. 3. Band 4 - Red Band and Band 5 - Near Infra-Red (NIR) from Landsat 8 (September, 2020, River Duruji Basin)

\section{Calculating of Normalized Difference Vegetation Index (NDVI)}

The Normalized Difference Vegetation Index (NDVI) is most commonly used to monitor green vegetation worldwide. Healthy vegetation is a good absorber of the visible electromagnetic spectrum. The chlorophyll contained in the greens absorbs the blue $(0.4-0.5 \mu \mathrm{m})$ and red $(0.6-0.7$ $\mu \mathrm{m})$ spectrum well and reflects the green $(0.5-0.6 \mu \mathrm{m})$ spectrum. Healthy plants have a high nearinfrared (NIR) reflectance of 0.7 to 1.3 micrometres [10].

Formula (1) gives Normalized Difference Vegetation Index (NDVI):

$$
N D V I=(\text { Band } 5-\text { Band } 4) /(N I R+\operatorname{Re} d)
$$

For Landsat 8 data:

$$
N D V I=(\text { Band } 5-\text { Band } 4) /(\text { Band } 5+\text { Band } 4)
$$

For determination of NDVI using GIS equation (1) will be:

$$
\text { Float("dem_b5_2013"-"dem_b4_2013")/ Float("dem_b5_2013"+"dem_b4_2013") }
$$

And

$$
\text { Float("dem_b5_2020"-"dem_b4_2020")/ Float("dem_b5_2020"+"dem_b4_2020") }
$$

After calculation of NDVI values using "raster calculator" we classified given results. The NDVI value varies from -1 to 1 . Higher the value of NDVI reflects high Near Infrared (NIR), means dense greenery. Generally, we obtain following result (see Fig. 4 and Fig. 5):

- $\mathrm{NDVI}=-1$ to 0 represent Water bodies - Non-Vegetation;

- $\mathrm{NDVI}=-0.1$ to 0.1 represent Barren rocks, land, sand, or snow - Sparse-Vegetation; Vegetation;

- NDVI $=0.2$ to 0.5 represent Shrubs and grasslands or senescing crops - Moderate

- $\mathrm{NDVI}=0.6$ to 1.0 represent Dense (Healthy) vegetation or tropical rainforest. 

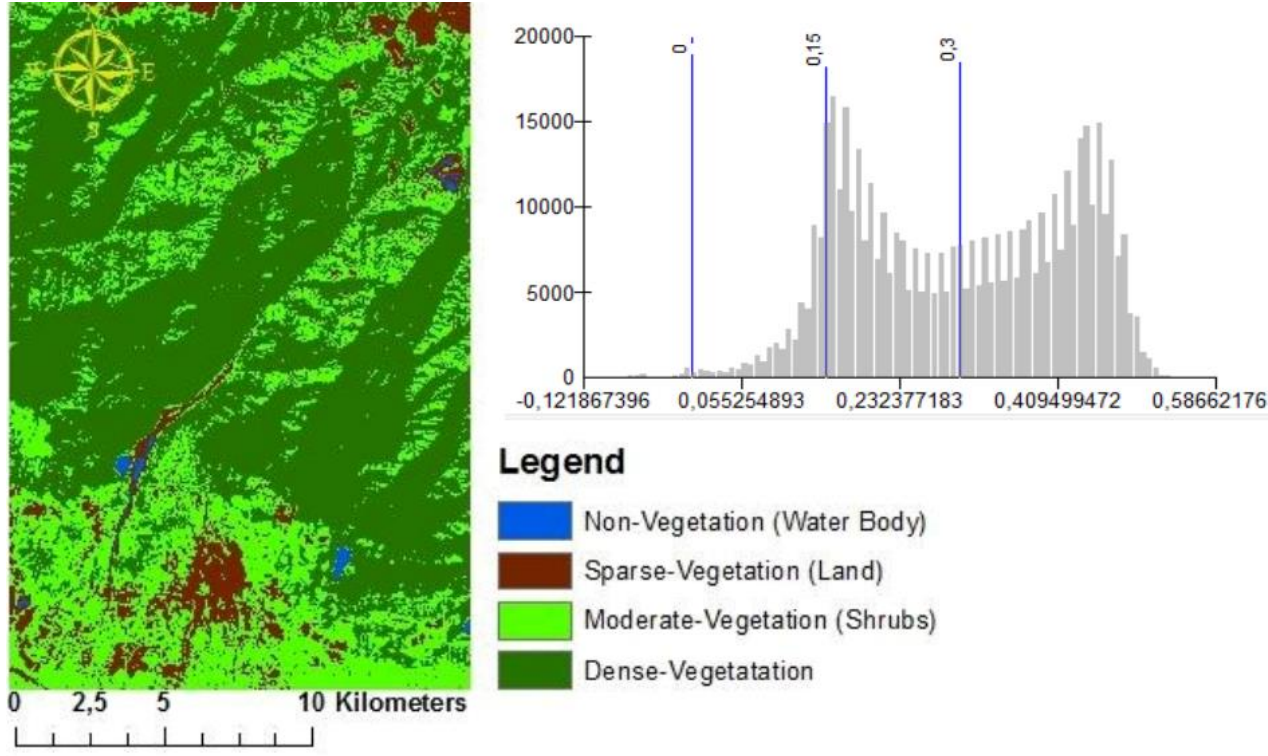

\section{Legend}

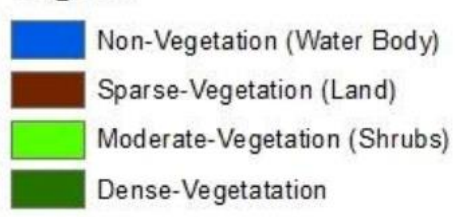

Fig. 4. Reclassified Map of Normalized Difference Vegetation Index (NDVI) \& Classification (September, 2013, River Duruji Basin)
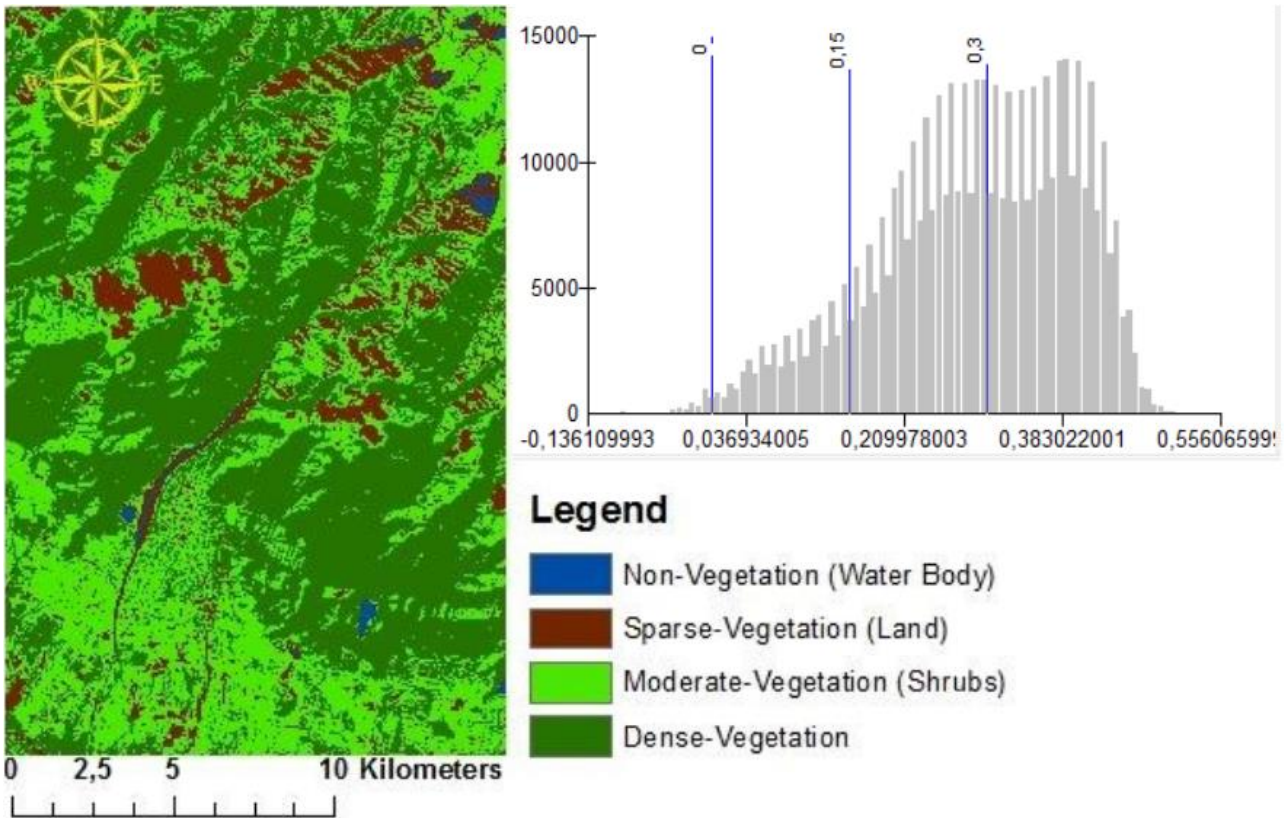

\section{Legend}

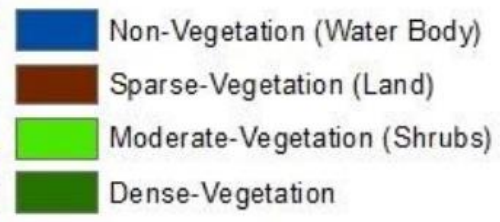

Fig. 5. Reclassified Map of Normalized Difference Vegetation Index (NDVI) \& Classification (September, 2020, River Duruji Basin)

Results and discussion. Based on the conducted research, relevant tables and graphs have been compiled for more visibility and analysis of the obtained results. Table 3 shows the obtained NDVI statistics for 2013 and 2020, while Table 4 analyses the dynamics of change between 20132020. The dynamics of change of areas is presented graphically bellow (see Fig. 6 and Fig. 7)

Table 3. Statistics of Normalized Difference Vegetation Index (NDVI)

\begin{tabular}{|c|c|c|}
\cline { 2 - 3 } \multicolumn{1}{c|}{} & NDVI (2013) & NDVI (2020) \\
\hline Minimum & -0.121867396 & -0.136109993 \\
\hline Maximum & 0.586621761 & 0.556065999 \\
\hline Mean & 0.3011671 & 0.287203957 \\
\hline Standard Deviation & 0.122903523 & 0.106652993 \\
\hline
\end{tabular}


Table 4. Changes of the NDVI densities between 2013 and 2020

\begin{tabular}{|c|c|c|c|c|c|c|c|c|c|}
\hline \multirow{2}{*}{$\begin{array}{c}\text { NDVI } \\
\text { Density } \\
\text { classes }\end{array}$} & \multicolumn{3}{|c|}{ NDVI (2013) } & \multicolumn{4}{c|}{ NDVI (2020) } & \multicolumn{3}{c|}{$\begin{array}{c}\text { Change } \\
\text { between } \\
\mathbf{2 0 1 3 - 2 0 2 0}\end{array}$} & $\begin{array}{c}\text { Average } \\
\text { Rate } \\
\text { Change }\end{array}$ \\
\cline { 2 - 10 } & Cells & ha & $\%$ & Cells & ha & $\%$ & ha & $\%$ & Ha/Year \\
\hline $\begin{array}{c}\text { NON- } \\
\text { vegetation }\end{array}$ & 1815 & 163,08 & 0,37 & 2901 & 260,66 & 0,60 & 97,58 & 0,22 & 13,94 \\
\hline $\begin{array}{c}\text { Sparse- } \\
\text { Vegetation }\end{array}$ & 47633 & 4279,94 & 9,78 & 52549 & 4721,66 & 10,79 & 441,71 & 1,01 & 63,10 \\
\hline $\begin{array}{c}\text { Moderate- } \\
\text { Vegetation }\end{array}$ & 188372 & 16925,70 & 38,69 & 189935 & 17066,14 & 39,01 & 140,44 & 0,32 & 20,06 \\
\hline $\begin{array}{c}\text { Dense- } \\
\text { Vegetation }\end{array}$ & 249100 & 22382,26 & 51,16 & 241535 & 21702,53 & 49,60 & 679,73 & - & $-97,10$ \\
\hline Total & $\mathbf{4 8 6 9 2 0}$ & $\mathbf{4 3 7 5 0 , 9 9}$ & $\mathbf{1 0 0 , 0 0}$ & $\mathbf{4 8 6 9 2 0}$ & $\mathbf{4 3 7 5 0 , 9 9}$ & $\mathbf{1 0 0 , 0 0}$ & & & \\
\hline
\end{tabular}

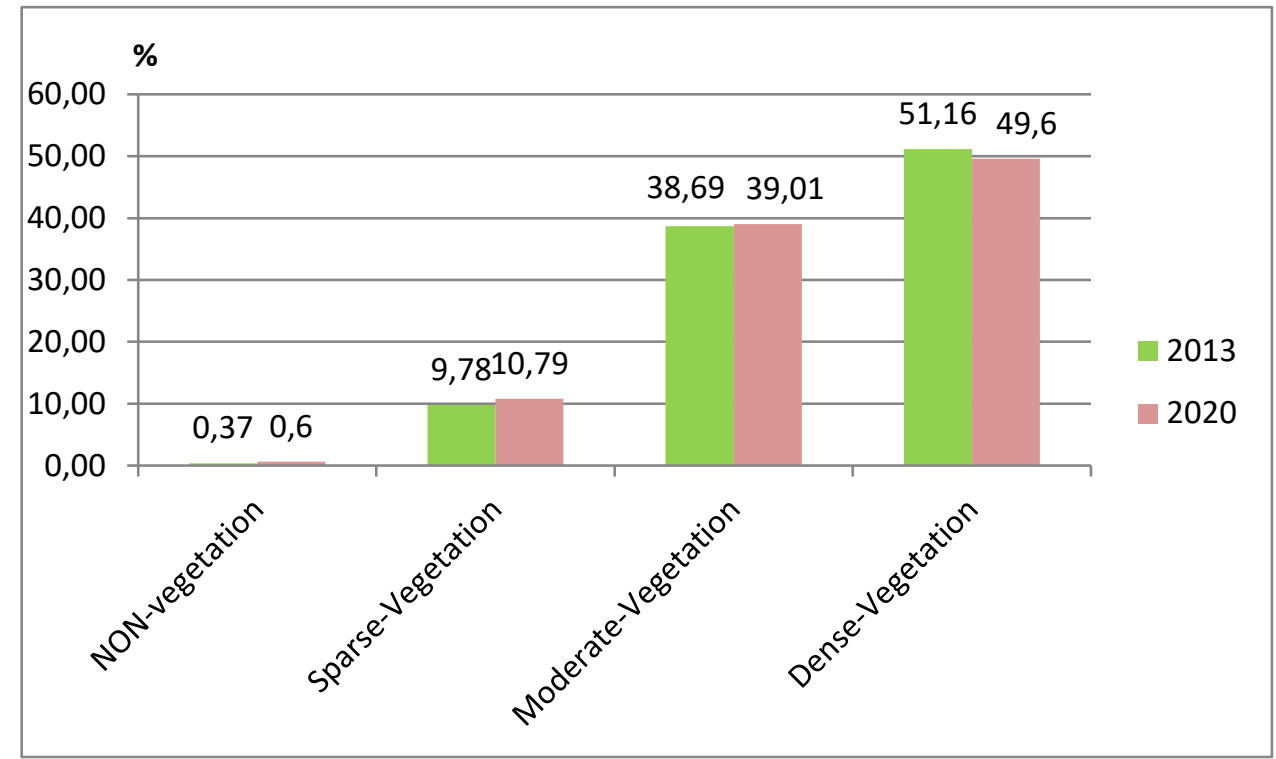

Fig. 6. Changes (\%) of the NDVI densities between 2013 and 2020

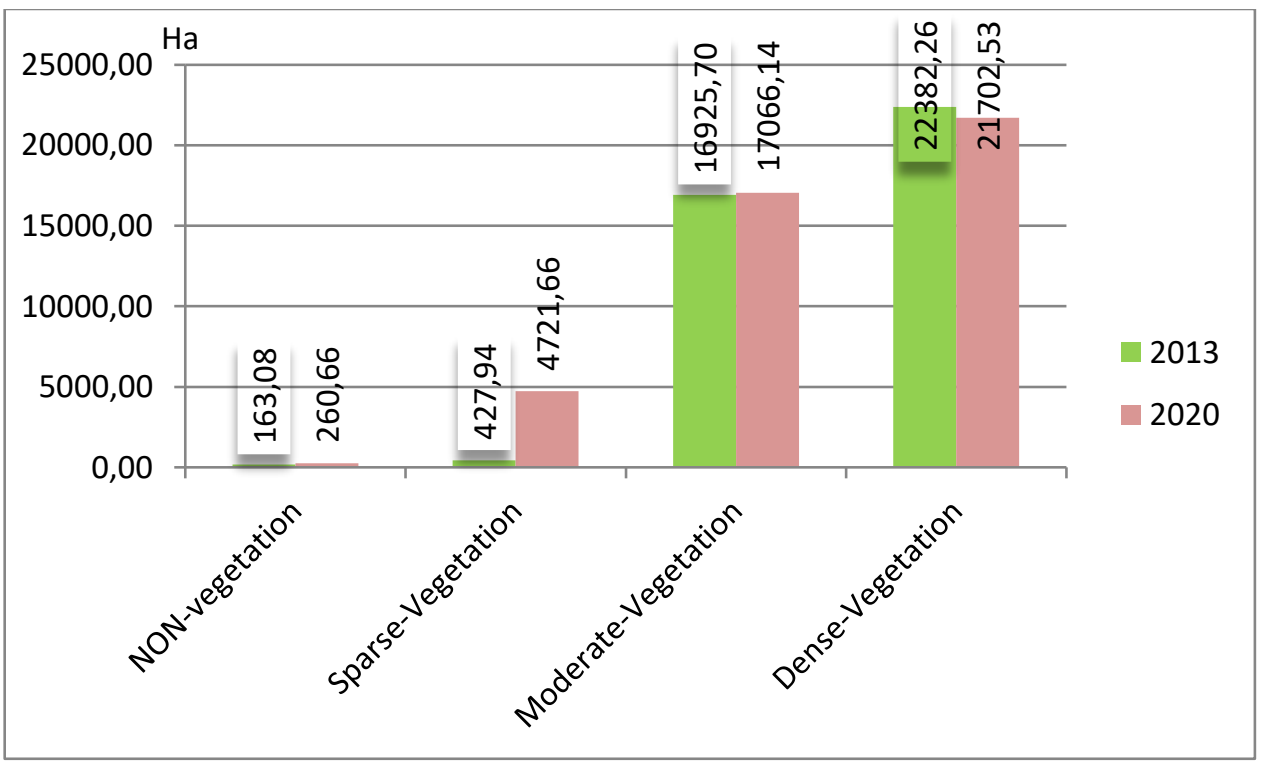

Fig. 7. Changes (ha) of the NDVI densities between 2013 and 2020 
Based on the analysis of the obtained tables and charts, we get that during 7 years (2013-2020) the Non-vegetation area increased by $0.22 \%$, Sparse-Vegetation - by $1.01 \%$ and Moderate-Vegetation - by $0.32 \%$, and the Dense-Vegetation area decreased by $1.55 \%$. At the same time, it was found that the annual increase in the Non-Vegetation area is approximately 13.94 hectares, with SparseVegetation - 63.10 hectares and with Moderate-Vegetation - 20.06 hectares, due to which the area with Dense-Vegetation has decreased by 97.10 hectares.

Based on the foregoing, if this trend continues to develop at the same pace, then by 2030 the loss of about 100 hectares of green cover is expected.

It should be noted that the Duruji River basin is characterized by an abundance of erosional cuts and there is an abundance of frequent floods of erosive genesis. Since green cover (vegetation) is one of the most important agronomic measures to prevent erosion, in light of its disappearance, it is expected that the rate of erosion will increase, and therefore the volume and area of the floodplain will increase, which is the subject of discussion for further research.

\section{REFERENCES}

1. Meera Gandhi.G, S. Parthiban, Nagaraj Thummalu, Christy. A. Ndvi: Vegetation change detection using remote sensing and gis - A case study of Vellore District. 3rd International Conference on Recent Trends in Computing 2015 (ICRTC-2015), Procedia Computer Science 57, 2015, 1199-1210.

2. Perminder Singh, Ovais Javeed. NDVI Based Assessment of Land Cover Changes Using Remote Sensing and GIS (A case study of Srinagar district, Kashmir). Sustainability, Agri, Food and Environmental Research, (ISSN: 0719-3726), 8(X), 2020: Retrieved from http://dx.doi.org/10.7770/safer-V0N0-art2174

3. Xie, Y., Zhao, X., Li, L., \& Wang, H. Calculating NDVI for Landsat7-ETM data after atmospheric correction using 6S model: A case study in Zhangye city, China. In 2010 18th International Conference on Geoinformatics, 2010, June. p. 1-4, IEEE.

4. Zhang, X., Hu, Y., Zhuang, D., Qi, Y., \& Ma, X. NDVI spatial pattern and its differentiation on the Mongolian Plateau. Journal of geographical sciences, 19(4), 2009, p. 403-415.

5. Hansen, M.C. - Loveland, T.R. (2012): A review of large area monitoring of land cover change using Landsat data. Remote Sensing of Environment. 122: 66-74.

6. Climate Change and Agriculture in Kakheti Region. Published with the support of the United Nations Development Programme (UNDP). Georgia, 2014. 238 p. Retrieved from https://www.ge.undp.org/content/georgia/en/home/library/environment_energy/climate-change-andagriculture-in-kakheti.

7. Local Economic Development Plan. Kvareli Municipality, Georgia. 2019. Retrieved from http://www.kvareli.gov.ge/sites/default/files/16._kvareli-ledp_eng_za_-_final.pdf

8. Gavardashvili G. Ecological problems of the Duruji River and innovative environmental measures. Publishing House "Universal". Tbilisi, 2018, 260 p. (In Georgian).

9. Retrieved from https://www.usgs.gov/faqs/what-are-best-landsat-spectral-bands-use-my-research?qtnews_science_products=0\#qt-news_science_products

10. Kshetri, Tek. NDVI, NDBI \& NDWI Calculation Using Landsat, 2018. Retrieved from https://www.linkedin.com/pulse/ndvi-ndbi-ndwi-calculation-using-landsat-7-8-tek-bahadur-kshetri 